Research Note

Journal of Extension Education

Vol. 29 No. 2, 2017

DOI:https: / / doi.org/10.26725/JEE.2017.2.29.5870-5874

\title{
Farmers' Awareness Level about ICT Tools and Services in Karnataka
}

\author{
Manjuprakash $^{1}$, H. Philip ${ }^{2}$ and N. Sriram ${ }^{3}$
}

\begin{abstract}
A study was undertaken to elicit the farmers' awareness about ICT tools and services in Karnataka. The study was conducted in Koppal district of Karnataka state with 120 respondents. It was found that more than half of the respondents had medium level of awareness on ICT tools and services. Majority of the respondents were aware of mobile advisory services by Agricultural Produce Market Committee (APMC). Almost twothirds of the respondents were aware of KCC (Kisan Call Centre) service. Slightly less than two-fourths of the respondents were aware of touch screen kiosks. The paper also discusses the awareness level of farmers on many other ICT tools.
\end{abstract}

Keywords : ICT, Mobile advisory; Social Networking; Awareness; Farmer; Karnataka

In the recent past, agriculture sector has become increasingly information-dependent, requiring a wide range of scientific and technical information for effective decision-making by the farming community (Cash, 2001).The role of ICTs as a medium of dissemination of information and knowledge in agricultural development has been widely recognized and discussed in the existing literature (Rao, 2008). Agricultural Institutions across the world have developed their own portals. Individuals and identical groups have started their blogs where- in relevant information based on needs of the followers are posted and updated.

Though there are number of ICT initiatives available to cater various solutions to the agricultural problems, farmers are not aware of several existing services. This study assesses the awareness and knowledge of the farmers on ICT schemes and projects in Karnataka

\section{METHODOLOGY}

The study was conducted in Koppal district of Karnataka state. Koppal district consists of four blocks and all the four blocks were selected for the study. By employing multi

1. Ph.D., Scholar, Department of Agricultural Extension, UAS, Bangalore, Karnataka. 2. Director of Extension Education, and 3. Associate Professor, Department of Agricultural Extension and Rural Sociology, Tamil Nadu Agricultural University, Coimbatore. India 
stage random sampling technique, two villages were selected from each block based on the area under more crops, progressiveness and the number of farmers. Belur and Mangalapur villages of Koppal block, Hanwal and Basapatna villages of Gangavathi block, Gonagera and Kandakur villages of Kushtagi block and Bevoor and Kuknoor villages of Yelaburga block were selected at random. Fifteen farmers from each selected villages were selected by employing multi stage random sampling technique and care was given to include all types of farmers without any bias. In total, 120 respondents were selected. Ex-post facto design was used for the study to meet out the objectives of the research. Appropriate statistical tools were employed to analyse the data collected.

\section{FINDINGS AND DISCUSSION}

Data in Table 1 depict the item-wise extent of awareness of the farmers on ICT tools and services.

Table 1.

Itemized Distribution of Respondents based on their Awareness
on ICT tools and Services

$(\mathrm{n}=120)$

\begin{tabular}{|c|c|c|c|c|c|c|c|c|c|c|c|c|c|}
\hline \multirow{3}{*}{$\begin{array}{l}\text { S1. } \\
\text { No. }\end{array}$} & \multirow{3}{*}{ ICT Tools } & \multicolumn{4}{|c|}{ Awareness } & \multicolumn{8}{|c|}{ Frequency of use } \\
\hline & & \multicolumn{2}{|c|}{ Aware } & \multicolumn{2}{|c|}{ Not aware } & \multicolumn{2}{|c|}{ Daily } & \multicolumn{2}{|c|}{$\begin{array}{c}\text { Once in a } \\
\text { week }\end{array}$} & \multicolumn{2}{|c|}{ Monthly } & \multicolumn{2}{|c|}{ Never } \\
\hline & & $\begin{array}{c}\text { Num } \\
\text { ber }\end{array}$ & $\begin{array}{c}\text { Per } \\
\text { cent }\end{array}$ & $\begin{array}{c}\text { Num } \\
\text { ber }\end{array}$ & $\begin{array}{c}\text { Per } \\
\text { cent }\end{array}$ & $\begin{array}{c}\text { Num } \\
\text { ber }\end{array}$ & $\begin{array}{c}\text { Per } \\
\text { cent }\end{array}$ & $\begin{array}{c}\text { Num } \\
\text { ber }\end{array}$ & $\begin{array}{c}\text { Per } \\
\text { cent }\end{array}$ & $\begin{array}{c}\text { Num } \\
\text { ber }\end{array}$ & $\begin{array}{c}\text { Per } \\
\text { cent }\end{array}$ & $\begin{array}{c}\text { Num } \\
\text { ber }\end{array}$ & $\begin{array}{l}\text { Per } \\
\text { cent }\end{array}$ \\
\hline \multirow[t]{8}{*}{1.} & \multicolumn{13}{|c|}{ Mobile Advisory } \\
\hline & m-Krishi & 70 & 58.30 & 50 & 41.70 & 4 & 3.30 & 00 & 00.00 & 1 & 0.80 & 115 & 95.80 \\
\hline & $\begin{array}{l}\text { IFFCO } \\
\text { Airtel }\end{array}$ & 61 & 50.80 & 59 & 49.20 & 7 & 5.80 & 2 & 1.70 & 1 & 0.80 & 110 & 91.70 \\
\hline & Nokia life tool & 39 & 32.50 & 81 & 67.50 & 2 & 1.70 & 0 & 0.00 & 0 & 0.00 & 118 & 98.30 \\
\hline & $\begin{array}{l}\text { RML (Reuters } \\
\text { Market Light) }\end{array}$ & 14 & 11.70 & 106 & 88.30 & 0 & 00.00 & 0 & 0.00 & 0 & 0.00 & 120 & 100.00 \\
\hline & DMI & 14 & 11.70 & 106 & 88.30 & 1 & 0.80 & 0 & 0.00 & 2 & 1.70 & 117 & 97.50 \\
\hline & KVK & 77 & 64.20 & 43 & 35.80 & 21 & 17.50 & 6 & 5.00 & 5 & 4.20 & 88 & 73.30 \\
\hline & APMC & 86 & 71.70 & 34 & 28.30 & 30 & 25.00 & 2 & 1.70 & 3 & 2.50 & 85 & 70.80 \\
\hline 2. & e-mail & 45 & 37.50 & 75 & 62.50 & 1 & 0.80 & 0 & 0.00 & 21 & 17.50 & 98 & 81.70 \\
\hline 3. & e-courses & 3 & 2.50 & 117 & 97.50 & 0 & 0.00 & 0 & 0.00 & 0 & 0.00 & 120 & 100.00 \\
\hline 4. & e-books & 1 & 0.80 & 119 & 99.20 & 0 & 0.00 & 0 & 0.00 & 0 & 0.00 & 120 & 100.00 \\
\hline 5. & $\begin{array}{l}\text { Kisan Call } \\
\text { Centre }\end{array}$ & 78 & 65.00 & 42 & 35.00 & 1 & 0.80 & 0 & 0.00 & 30 & 25.00 & 89 & 74.20 \\
\hline
\end{tabular}




\begin{tabular}{|c|c|c|c|c|c|c|c|c|c|c|c|c|c|}
\hline \multirow{3}{*}{$\begin{array}{l}\text { S1. } \\
\text { No. }\end{array}$} & \multirow{3}{*}{ ICT Tools } & \multicolumn{4}{|c|}{ Awareness } & \multicolumn{8}{|c|}{ Frequency of use } \\
\hline & & \multicolumn{2}{|c|}{ Aware } & \multicolumn{2}{|c|}{ Not aware } & \multicolumn{2}{|c|}{ Daily } & \multicolumn{2}{|c|}{$\begin{array}{c}\text { Once in a } \\
\text { week }\end{array}$} & \multicolumn{2}{|c|}{ Monthly } & \multicolumn{2}{|c|}{ Never } \\
\hline & & $\begin{array}{c}\text { Num } \\
\text { ber }\end{array}$ & $\begin{array}{l}\text { Per } \\
\text { cent }\end{array}$ & $\begin{array}{c}\text { Num } \\
\text { ber }\end{array}$ & $\begin{array}{l}\text { Per } \\
\text { cent }\end{array}$ & $\begin{array}{c}\text { Num } \\
\text { ber }\end{array}$ & $\begin{array}{c}\text { Per } \\
\text { cent }\end{array}$ & $\begin{array}{c}\text { Num } \\
\text { ber }\end{array}$ & $\begin{array}{l}\text { Per } \\
\text { cent }\end{array}$ & $\begin{array}{c}\text { Num } \\
\text { ber }\end{array}$ & $\begin{array}{c}\text { Per } \\
\text { cent }\end{array}$ & $\begin{array}{c}\text { Num } \\
\text { ber }\end{array}$ & $\begin{array}{l}\text { Per } \\
\text { cent }\end{array}$ \\
\hline \multirow[t]{5}{*}{6.} & \multicolumn{13}{|c|}{ Video Conferencing } \\
\hline & Skype & 45 & 37.50 & 75 & 62.50 & 0 & 0 & 1 & 0.80 & 4 & 3.30 & 115 & 95.80 \\
\hline & IMO & 29 & 24.20 & 91 & 75.80 & 0 & 0 & 0 & 0.00 & 1 & 00.80 & 119 & 99.20 \\
\hline & Google Talk & 10 & 8.30 & 110 & 91.70 & 0 & 0 & 0 & 0.00 & 0 & 0.00 & 120 & 100.00 \\
\hline & OoVoo & 1 & 0.80 & 119 & 99.20 & 0 & 0 & 0 & 0.00 & 0 & 0.00 & 120 & 100.00 \\
\hline 7. & $\begin{array}{l}\text { Touch } \\
\text { screen } \\
\text { kiosks }\end{array}$ & 77 & 64.20 & 43 & 35.80 & 1 & 0.8 & 3 & 2.50 & 52 & 43.30 & 64 & 53.30 \\
\hline 8. & \multicolumn{13}{|c|}{ Social Networking Tools } \\
\hline & WhatsApp & 81 & 67.50 & 39 & 32.50 & 27 & 22.5 & 18 & 15.00 & 5 & 4.20 & 70 & 58.30 \\
\hline & Facebook & 80 & 66.70 & 40 & 33.30 & 27 & 22.5 & 16 & 13.30 & 5 & 4.20 & 72 & 60.00 \\
\hline & Twitter & 47 & 39.20 & 73 & 60.80 & 1 & .8 & 0 & 0.00 & 1 & 0.80 & 118 & 98.30 \\
\hline & Hike & 43 & 35.80 & 77 & 64.20 & 0 & 0 & 1 & 0.80 & 0 & 0.00 & 119 & 99.20 \\
\hline & Instagram & 34 & 28.30 & 86 & 71.70 & 0 & 0 & 2 & 1.70 & 0 & 0.00 & 118 & 98.30 \\
\hline & Blog & 9 & 7.50 & 111 & 92.50 & 0 & 0 & 0 & 0.00 & 0 & 0.00 & 120 & 100.00 \\
\hline
\end{tabular}

\section{Mobile Advisory}

Majority $(71.70 \%)$ of the respondents were aware of mobile advisory services by APMC (Agricultural Produce Market Committee) in regard of agricultural commodity prices and market for the various commodities. This is because of the presence of wellestablished APMCs in all the block of the district and the regular dissemination of text message to the registered farmers regarding the market conditions. Onefourth $(25.00 \%)$ of the respondents were using mobile advisory facility offered by APMC on daily basis. About 2.50 per cent of the farmers had used once in a month. But, majority $(70-80 \%)$ of the respondents had never used this facility by registering their mobile number for receiving text message. Many of them being small and marginal farmers, they did not have surplus produce for sale in the market.

Less than two-thirds (64.20\%) of the respondents, were aware of the mobile advisory services provided by KVK and exactly one-fourth $(25.00 \%)$ of the respondents used this service on a daily basis. Many farmers participate in KVK activities such as demonstrations 
Farmers' Awareness Level about ICT Tools and Services in Karnataka

and meetings, and become aware of the mobile advisory service provided by the KVK.

Less number of respondents had awareness on mobile telephony by RML and DMI (Dynamic Market Information) None of the respondents used RML facility due to lack of awareness on how to and where to register to avail the facility. A negligible percentage of the respondents used DMI mobile telephony on daily (0.80 $\%)$ and on monthly (1.70 \%) basis.

With respect to the awareness on mkrishi and IFFCO Airtel mobile advisory, 58.30 per cent and 50.80 per cent of the respondents were aware of the services respectively. mkrishi \& IFFCO Airtel were used by 3.30 per cent of the respondents.

Almost one-third (32.50\%) of the respondents were aware of Nokia Life Tool mobile advisory service and only 1.70 per cent of the respondents had used this service on daily basis. Since these are paid services, awareness as well as usage is very low among the respondents.

\section{2. e-Mail}

e-Mail is a medium of formal communication used mainly for official purposes. Over one-third (37.50\%) of the respondents were aware of e-mail.

\section{3. e-Course and e-Books}

Very less number of respondents were aware of e-course $(2.50 \%)$ and e-books $(0.80 \%)$. This might be because of lack of digital literacy among the respondents. None of the respondents used e-course and e-books for agricultural and non-agricultural purposes.

\section{Kisan Call Centre (KCC)}

Almost two-thirds (65.00\%) of the respondents were aware of $\mathrm{KCC}$ service. Little less than three-fourths (74.20\%) of the respondents had never used Kisan Call Centre for agricultural purpose. This might be due to inability of the persons working in the KCC to provide workable solutions.

\section{Video Conferencing}

The respondents had awareness about video conferencing tools such as Skype (37.50 \%), IMO (24.20 \%), Google Talk (08.30\%) and very negligible per cent $(0.80 \%)$ of the respondents were aware of oovoo. The usage pattern of video conferencing was very poor. This might be due to the lack of proper connectivity available at villages, lack of guidance and skills in using the tools.

\section{Touch Screen Kiosks}

A little less than two-fourths (64.20 $\%)$ of the respondents were aware of touch screen kiosks. Usage pattern of the respondents was very poor as they rarely visit the extension and departmental offices. More than half (53.30\%) of the respondents had never used kiosks. The probable reason might be due to the infrequent visit of these people to the development departments. 


\section{Social Networking Tools}

Majority of the respondents were aware of WhatsApp (67.50\%) and Facebook (66.70 \%). Majority of them had never used WhatsApp (58.30\%) and Facebook (60.00\%). This might be due to poor connectivity of the network, access to internet and usage of basic mobile handsets.

As more than half of the respondents had medium level of awareness on ICT tools and services, the potential of the ICT tools may be harnessed in advisory services and data collection to improve agricultural production and uplift the economy of the farmers.

\section{REFERENCES}

Aker, J. C. (2011). Dial "A" for agriculture: a review of information and communication technologies for agricultural extension in developing countries. Agricultural Economics, 42, 631-647.

Cash, D. W. (2001). In Order to Aid in Diffusing Useful and Practical Information: Agricultural Extension and Boundary Organizations. Science Technology Human Values, 26, 431453.

Koshy, S.M \& Kishore Kumar, N. (2016). Attitude of Farmers towards Kisan Call Centres. Journal of Extension Education, 28(4)

Rao, S. S. (2008). Social Development in Indian Rural Communities: Adoption of Telecentres. International Journal of Information Management, 28, 474482 . 